\title{
Wydział Prawa Kanonicznego Uniwersytetu Papieskiego Jana Pawła II w Krakowie
}

Kongregacja ds. Edukacji Katolickiej dekretem z 19 marca 2014 roku - czyli w uroczystość św. Józefa, Oblubieńca Najświętszej Maryi Panny, a zarazem w roku kanonizacji błogosławionego papieża Jana Pawła II - erygowała Wydział Prawa Kanonicznego Uniwersytetu Papieskiego Jana Pawła II w Krakowie.

Pierwszym dziekanem wydziału został ks. prof. zw. dr hab. Tomasz Rozkrut.

Utworzenie Wydziału Prawa Kanonicznego nawiązuje do bogatej historii nauczania prawa kanonicznego w Krakowie, które w latach 1999-2014 realizował Instytut Prawa Kanonicznego, a którego początki wiążą się z utworzeniem Uniwersytetu Jagiellońskiego. Zapisał bowiem następująco ks. prof. Tadeusz Pawluk: „nauczaniu prawa kanonicznego w Polsce wysoką rangę nadał Uniwersytet Krakowski. W akcie fundacyjnym Kazimierza Wielkiego z dnia 12 maja 1364 roku wydział prawa, w porównaniu z pozostałymi wydziałami, tj. sztuk wyzwolonych i medycyny, został jakby uprzywilejowany. Na przewidzianych jedenastu profesorów uczelni, aż ośmiu miało kierować katedrami prawniczymi. Przewidziane były trzy katedry prawa kanonicznego oraz pięć katedr prawa rzymskiego. Pierwsza z katedr prawa kanonicznego była poświęcona Dekretowi Gracjana, druga - Dekretałom Grzegorza IX, trzecia zaś - Księdze vi Bonifacego VIII i Klementynom" (T. Pawluk, Prawo kanoniczne według Kodeksu Jana Pawła II, t. 1, Olsztyn 1985, s. 58).

Podziękowanie za osobiste zaangażowanie w powstanie Wydziału Prawa Kanonicznego, składamy Jego Eminencji kard. Stanisławowi Dziwiszowi - Wielkiemu Kanclerzowi Uniwersytetu Papieskiego Jana Pawła II w Krakowie, który wcześniej także usilnie zabiegał, aby w królewskim Krakowie powstał papieski uniwersytet kościelny. 
Wydział Prawa Kanonicznego powstał dzięki usilnym staraniom dyrektora Instytutu Prawa Kanonicznego ks. prof. dr. hab. Józefa Krzywdy cm przy współudziale nauczycieli akademickich Instytutu Prawa Kanonicznego, w szczególności ks. prof. dr. hab. Jana Dyducha, inicjatora oraz pierwszego dyrektora Instytutu Prawa Kanonicznego i sukcesywnie pierwszego rektora Uniwersytetu Papieskiego Jana Pawła II w Krakowie. 
N. $175 / 2011$

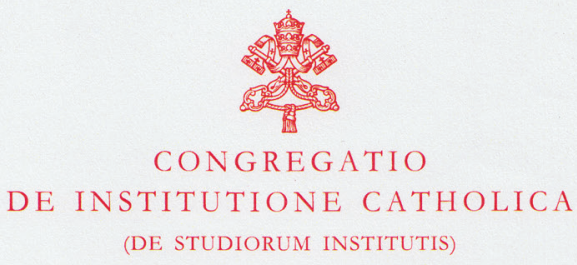

DECRETUM

CongRegatio De InSTITUTIONE CATHOLICA (DE STUdiorum InSTITUTIS), attentis litteris postulatoriis Em.mi ac Rev.mi Stanislai Cardinalis Dziwisz, Archiepiscopi Metropolitæ Cracoviensis, Pontificiæ Universitatis Cracoviensis Ioannis Pauli II Magni Cancellarii legitime præsentantis, re undique perpensa, ad normam Constitutionis Apostolicæ Sapientia christiana

\section{FACUlTATEM IURIS CANONICI}

\section{Pontificia UNiversitatis Cracoviensis IOANNIS PAULI II}

pro munere hoc Decreto academice erigit erectamque declarat; facta eidem potestate academicos Licentix ac Doctoratus gradus ad normam canonicarum de studiis superioribus legum rite conferendi, servatis præscriptionibus Apostolicæ Constitutionis Sapientia christiana Ordinationibusque eidem adnexis, peculiaribus Statutis eiusdem Facultatis ab hac Congregatione approbatis, ceteris servatis de iure servandis, contrariis quibuslibet minime obstantibus.

Datum Romæ, ex ædibus eiusdem Congregationis, die XIX mensis Martii, in sollemnitate S. Ioseph sponsi B. Mariæ Virginis, a. D. MMXIV.

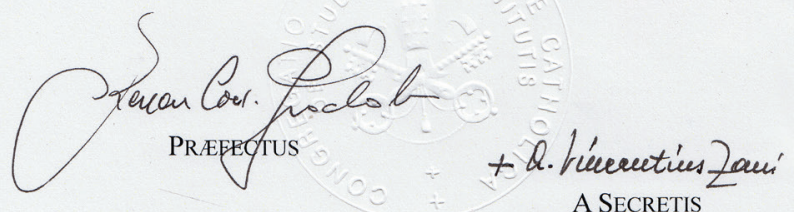

A SECRETIS 